\title{
Information on Financial Statements for Loan Decision-Making of Commercial Banks in Vietnam
}

\author{
Mai Thi Hoang Minh \\ University of Economics, Ho Chi Minh City, Vietnam
}

\begin{abstract}
Financial statements (FS) are tools which provide information to users for making business decisions. Among the organizations, banks are the firms which conducted and did business with risks. In particular, commercial banks continue to play a dominant role in the whole system, and local commercial banks still have an edge in its widespread network across the country over foreign banks. This article is going to present the survey which clarifies the role of FS in commercial banks' loan decisions in Vietnam. Moreover, this paper also discusses FS's quality currently, thereby making suggestions for enterprises to enhance the usefulness of accounting information in borrowing activities. This paper has taken performance with 74 official employees in commercial banks in Vietnam. The results indicated the qualitative characteristics of banks when disclosing the financial statements. This article also gave the six oriented solutions to improvement of the loan decision-making by banks.
\end{abstract}

Keywords: usefulness of financial statement (FS), accounting information quality, loan decisions, banking

\section{Introduction}

The quality of accounting information is evaluated by its usefulness to users. At present, based on the Ministry of Finance (2013) and the International Accounting Standards Board (IASB, 2010), criteria used to identify the usefulness of accounting information are displayed in the Conceptual Framework for Financial Reporting, and the requirements for accounting information in Vietnam are stated in Vietnamese Accounting Standards No. 1 (VAS 01). In fact, the usefulness of accounting information for users has been studied quite early. Recent researches have showed some issues related to quality of financial reporting in Vietnam which makes them less useful to loan decisions (Nichols, 1997). This study continues to learn more about financial reporting's quality issues to make specific recommendations which help enhance their usefulness for business borrowing activities.

\section{Results of Previous Researches About How Accounting Information Has Affected Loan Decisions}

\section{General Information}

Previous researches showed that accounting information plays an important role in banks in developed economies. Since the 1970s, banks in USA have considered financial reporting as the most important source for loan decisions (Stanga \& Benjamin, 1978). This information can change the decisions of commercial banks

Mai Thi Hoang Minh, associate professor, doctor of Accounting, vice dean of Principle Accounting Department, School of Accounting and Auditing, University of Economics. Email: hminh09@gmail.com. 
(Danos, Holt, \& Imhoff, 1989). Operating cash flow was demonstrated to have a close relationship with credit risk at enterprises which have high long-term loan rates or less business risks (Independent Evaluation Group [IEG], 2010).

Information used for making loan decisions is plenty and its roles vary by country. In USA, credit history information, project's financial reporting, financial operating cash flow, detail of fixed assets, and indirect cash flow statement are the most important (Catanach \& Kemp, 1999). Meanwhile in Hong Kong, information from note in financial statements (FS) is the most exploited, while information on cash flow takes the next concern (Kwok, 2002; Marian, Lui, \& Lew, 2002).

In Australia, each financial statement is exploited from a different angle, e.g., cash flow statement is used to evaluate the payment ability to make loan decisions. Balance sheet plays the assessment and monitoring roles and income statement is considered important when appraising the enterprise's operation (Jones, 1998; Kitindi, Magembe, \& Sethibe, 2007).

This role of accounting information to loan decisions in developing countries is less important. It is proved by individual country and showed that the quality of information on FS does not satisfy users in general and banks in particular.

Consequently, information on FS is not considered important when making decisions (Abu-Nassar \& Rutherford, 1996; Dang, N. Marriott, \& P. Marriott, 2006; 2008). The common issues of accounting information are delays, lack of reliability, and incomplete notes (Mirshekary \& Saudagaran, 2005). However, FS is still used as a source of information. Income statement and balance sheet are most widely used. Especially, audited information will be more valuable.

\section{Research Method}

This article summarized information from FS analysis process of 10 commercial banks in Vietnam and surveyed 74 credit staffs to learn the role of information in the FS for making decisions for loans as well as for assessing their quality. Statistical inference methods and calibration techniques pair-sample $t$-test are used for data processing. Although the number of staffs surveyed in each bank was not large, the survey was distributed across multiple banks to ensure representativeness. Moreover, each bank applies loan process and FS analysis techniques consistent with all of their branches, hence, some branches can also be capable of representing the entire.

\section{Criterion for Evaluating the Usefulness of Accounting Information in Accordance With International Accounting Standards}

The quality of accounting information is evaluated by its usefulness to users. According to FS theory, properties affecting the usefulness of accounting information include two main quality indicators and four secondary quality indicators as follows.

\section{The Main Quality Indicators}

The main quality indicators include "Relevant" and "True".

Relevant information is likely to create a difference or can change users' decisions. This feature is disclosed through the predicted value and asserted value. Value prediction means that information can be used as input data for a process which helps users predict future results. Value assertion is presented by the feedback from predicted value (Al-Razeen \& Karbhari, 2004). 
True information must have three properties: completeness, neutrality, and no errors. Completeness means presenting all necessary information so that users can understand what the phenomenon mentions about, including detailed descriptions and related explanations.

Neutrality means that information contained in the FS must be free from bias. It should reflect a balanced view of the affairs of the company without attempting to present them in a favored light. Information may be deliberately biased or systematically biased. Neutral or reliable accounting information does not target interests of specific users of accounting information (i.e., does not favor certain users of accounting information over the others) and presents the actual position of banking. No error does not mean absolutely having no error, and the information on the report must be generated from fairly chosen processes. Besides, no error is found when applying those processes.

\section{Additional Quality Indicators}

Additional quality indicators include comparability, verifiability, timeliness, and understandability. These indicators enhance the usefulness of information which is identified as relevant and true.

Comparability helps users to indicate the similarity and difference among items, normally related to two items or more.

Verifiability means that independent observers who have knowledge in various fields can still agree that the information is presented truly. The verification can be done first through observation (direct) or checking the input of the calculation method and then by recalculating the result using the same method (indirect).

Timeliness means that information must be transferred to users to make decisions at the point time and can affect their decisions.

Understandability means that information should be classified, described, and presented in a clear and concise way.

\section{Information on FS for Loan Decisions of Commercial Banks in Vietnam and Quality Assessment}

\section{Role of FS in Loan Processes}

In comparison with other elements affecting loan decisions in Vietnam, FS just plays an average role, much lower than information provided by independent organizations. It has five levels of information in banking statements as illustrated in Table 1 . This partly reflects low trustfulness of banks on information provided by enterprises compared with other sources.

Table 1

Units for Magnetic Properties

\begin{tabular}{|l|l|}
\hline No. & Content \\
\hline 1 & The information from credit center, assurance assets, customer's business plan, and direct check \\
\hline 3 & Intuition of decision-maker \\
\hline 4 & FS and tax reports \\
\hline 5 & $\begin{array}{l}\text { The information from internal chart } \\
\text { bank's leaders/other clients, and the third party guarantee }\end{array}$ \\
\hline
\end{tabular}

Information from checking customers directly and assurance asset value are also much more important than that from FS. It indicates that most banks do not rely on the information provided by enterprises but apply other strategies to minimize credit risks. Customers’ business plans are highly considerable. 
It means that there is a great need for information helping predict future events. Intuition in decision processes plays a rather important role which reinforces the judgment that banks in Vietnam make decisions by emotional orientation model rather than by rational model.

\section{Information From the FS Exploited by the Banks}

There is a small difference in using financial statements among banks in Vietnam. However, in general ways, FS is used in the following process: First of all, enterprises are required to submit FS of 2-3 years, depending on the nature of the loan. Less financial statements are required for short-term loans than mediumor long-term loans. FS required includes: balance sheets, income statements, cash flow statements (if yes), and notes for FS. Then, credit staffs are asked to check the accuracy of those statements. Common techniques applied are checking the audited reports, reconciling with tax reports, visiting the enterprises' working places, recalculating the data on FS, etc.. Finally, FS of banks will be analyzed by tool of analysis in trend or ratio analysis for learning the financial and operating status and predicting the repayment ability of customers.

Recent researches have showed that income statements are mostly used, followed by balance sheets. Two remained reports are used at a lower level. For each FS, the information usage level is also uneven. The information items used in the FS are displayed in Tables 2 and 3.

Table 2

Information Used by Over 70\% of Banks When Analyzing FS

\begin{tabular}{|l|l|}
\hline Type of FS & Main content in those official reports \\
\hline Balance sheets & $\begin{array}{l}\text { 1. General data: total assets, short-term assets, long-term assets, total equity, short-term equity, } \\
\text { long-term equity, equity, short-term liabilities, and long-term liabilities. } \\
\text { 2. Detail data: inventory, account receivable. }\end{array}$ \\
\hline Income statements & $\begin{array}{l}\text { 1. General data: total revenue, gross profit, operating profit, profit before tax and interest } \\
\text { expenses, and profit after tax, } \\
\text { 2. Detail data: cost of sales, depreciation expenses, and interest expenses. }\end{array}$ \\
\hline Note for FS & $\begin{array}{l}\text { 1. Debt to credit institutions and interest of loans. } \\
\text { 2. Fixed assets used as assurance for loans. } \\
\text { 3. The number of customers and receivable recollect time. } \\
\text { 4. Details revenue for each industry, sector, and geographic region. }\end{array}$ \\
\hline
\end{tabular}

Table 3

Information Used by Less Than 30\% of Banks When Analyzing FS

\begin{tabular}{|l|l|}
\hline Type of FS & Main content in those official reports \\
\hline Balance sheets & Financial investment, other assets, other liabilities, and capital contributed by owners. \\
\hline Income statements & Selling expenses, admin expenses. \\
\hline Cash flow statements & $\begin{array}{l}\text { Cash flows from operating activities, cash flows from selling, and cash flows from operating } \\
\text { expense. }\end{array}$ \\
\hline Note for FS & $\begin{array}{l}\text { 1. Accounting system, principles of business accounting. } \\
\text { 2. Detailed financial investments of enterprises, distinction between investments in equity } \\
\text { securities and investments in debt securities. } \\
\text { 3. Fixed assets involved serving major business activities. }\end{array}$ \\
\hline
\end{tabular}

\section{Evaluation of the Banks on the Quality of Information Provided by FS}

Comparison between expectations and reality shows that the quality of corporate FS is rated quite low by the bank. They failed to reach the "standards" on most basic quality criteria, in which the "Fair" feature was the most unsatisfactory. General purpose FS is designed to meet the needs of many diverse users, particularly present and potential owners and creditors. FS results from simplifying, condensing, and aggregating masses of 
data obtained primarily from a company's accounting system. They sometimes are unable to reflect the real situation of that firm at that time for presented FS.

The accounting estimates are not clearly explained and the method of estimate is unreasonable. These reasons make the FS reduce its relevance for decision-making and partly explain the reason why the FS failed to play the important role in lending decisions (Nguyen, 2008).

Besides the above unappreciated factors, FS now achieved some certain requirements of the banks. Specifically, banks do not require changing the method of evaluating the value of assets or current liabilities. At the same time, they are also satisfied with the classification and presentation of current information.

\section{Application of the Research: Improving the Quality of FS Information for the Sake of Borrowing}

Based on the above results, this paper has suggested the followings to improve the quality of FS information (demonstrated in Tables 4 and 5) and enhance the usefulness of accounting information for lending activities.

Table 4

The Qualitative Characteristics of FS That Met the Expectations of Banks

\begin{tabular}{|l|l|l|}
\hline No. & The current requirement that FS has met the expectations of banks & Qualitative characteristic \\
\hline 1 & The values of assets and liabilities are calculated in a reasonable manner & Faithful representation \\
\hline 2 & Information is classified and presented for an easy comparison during the period & Comparability \\
\hline 3 & Understandable & Understandability \\
\hline
\end{tabular}

Table 5

The Qualitative Characteristics of FS That Did Not Meet the Expectations of Banks

\begin{tabular}{|l|l|l|}
\hline No. & The current requirement that FS has not met the expectations of banks & Qualitative characteristic \\
\hline 1 & FS reflects the real situation of the customer & $\begin{array}{l}\text { Faithful representation (completeness, } \\
\text { neutrality) }\end{array}$ \\
\hline 2 & The accounting estimates are explained explicitly and fully in FS & Faithful representation (completeness) \\
\hline 3 & The FS presents no bias in favor of the borrower & Faithful representation (neutrality) \\
\hline 4 & Information on FS can be verifiable & Verifiable \\
\hline 5 & Additional information on special events happening in enterprises is fully provided & Faithful representation (completeness) \\
\hline 6 & Information should be provided promptly & Timeliness \\
\hline 7 & $\begin{array}{l}\text { Information could help predict future outcomes and test the results predicted in the } \\
\text { past }\end{array}$ & Relevance \\
\hline 8 & The estimates were calculated reasonably & Faithful representation \\
\hline
\end{tabular}

The causes which have made FS in Vietnam fail to achieve qualitative characteristics, as have been shown in previous studies, are the lack of awareness of business owners in providing truthful information to the outside and the weak level of a lot of accountants. Therefore, in order for the information provided to ensure "completeness" and "neutrality", business owners need to be aware of the benefits of providing truthful information to business.

Based on Nguyen, Le, and Jerman (2007), that awareness will motivate them to recruit qualified accountants, train and encourage them to update their knowledge, and improve the professional knowledge for accountants, and in the meantime, the business owners themselves also need to understand that publishing FS honestly is a way to help build and strengthen corporate reputation with external partners.

For accountants, this article has some suggestions for improving the quality of accounting information for lending activities: 
(1) In terms of accounting estimates (estimates of doubtful receivables, obsolete inventory value, product warranty obligations, etc.): They need to be reviewed for developing, implementing, and disclosing information. Vietnam has had some legal documents which show the method for calculating the accounting estimates. This is required by VAS; however, the current study showed that the borrowers do not perform well. The documents guiding the implementation of the current accounting estimates are Circular 228/2009/TT-BTC and Circular 89/2013/TT-BTC. Businesses can refer to these documents but we should note that the above guidelines are documents which serve for calculating deductible expenses when calculating corporate income tax. Therefore, there are some points which might not fit in the actual business activities. Businesses should develop written procedures for estimates of their own instead of just copying the instructions of tax authorities. The process should also be reviewed over time, and should also be assessed if old processes and estimation methods are still reasonable and make appropriate adjustments when necessary. Presentation of details of the estimate method not only enhances the completeness of the FS, but also helps increase the verifiability;

(2) Complete presentation of loans and fixed assets used as collateral for business loans. This information is important which once disclosed can help FS users make some predictions about future obligations as well as financial risk assessment of the business. The discloser of this information helps increase the relevance of FS and give a true and fair view of FS. For banks, this information can be found through their own information systems, however, complete disclosure of information will help increase the timeliness of the information, and the verification investigation will take place more smoothly and help shorten the time to consider the loan application;

(3) For fixed assets, in addition to sorting out in the current form, businesses should consider the track record of fixed assets, classified as fixed assets for main operations of business and fixed assets not serving the main business activity;

(4) Although it is not financial information but survey shows information about the board of directors, the history of the company is also interested in finding out more in the lending process. Enterprises should prepare this information and may consider disclosure in the notes to FS or other statements included;

(5) With business operating in many sectors or many regions, it is necessary for information systems management, account details, etc., to record accounting information effectively and efficiently, so that business is able to track revenues and expenses separately according to sectors and geographical areas. This will provide useful information for the evaluation of performance of the business. Those unlisted enterprises are also advised to disclose segment information in FS under the guidance of the VAS No. 28, "Segment Reporting";

(6) Disclosure of information on important current events is also evaluated as unsatisfactory, reducing the relevance of FS information. Therefore, prior to publication of the FS, the organizations should review all information and events which are not mentioned on FS but are significant, such as contingent liabilities, commitments, events of related parties, etc..

\section{Conclusion}

The quality of FS is always cared by both business and other users. Under the gaze of the commercial banks, based on the quality of financial information, Vietnamese FS of banking has faced many issues together with problems, in which faithful representation is most underrated. This article gives some suggestions for enterprises to improve the faithful representation, relevance, and timeliness of FS, thereby making them more useful to borrowing activities of business. 


\section{References}

Abu-Nassar, M., \& Rutherford, B. A. (1996). External users of financial reports in less developed countries: The case of Jordan. The British Accounting Review, 28(1), 73-87.

Al-Razeen, A., \& Karbhari, Y. (2004). Annual corporate information: Importance and use in Saudi Arabia. Managerial Auditing Journal, 19(1), 117-133.

Catanach, A. H., \& Kemp, R. S. (1999). The information needs of bank lending officers. Commercial Lending Review, 14(3), 76-78.

Dang, D. S., Marriott, N., \& Marriott, P. (2006). Users' perceptions and uses of financial reports of small and medium companies (SMCs) in transitional economies: Qualitative evidence from Vietnam. Qualitative Research in Accounting and Management, 3(3), 218-235.

Dang, D. S., Marriott, N., \& Marriott, P. (2008). The banks' uses of smaller companies' financial information in the emerging economy of Vietnam: A user's oriented model. In M. Tsamenyi, \& S. Uddin (Eds.), Corporate governance in less developed and emerging economies (Vol. 8, pp. 519-548). Emerald Group Publishing Limited.

Danos, P., Holt, D., \& Imhoff, E. (1989). The use of accounting information in bank lending decisions. Accounting, Organizations, and Society, 14(3), 235-247.

Independent Evaluation Group [IEG]. (2010). An evaluation of World Bank support, 2002-08: Gender and development. World Bank, IFC, MIGA. Retrieved from http://ieg.worldbank.org/Data/reports/gender_eval.pdf

International Accounting Standards Board [IASB]. (2010). Conceptual framework for financial reporting.

Jones, S. (1998). An evaluation of user ratings of cash vs. accrual based financial reports in Australia. Managerial Finance, 24(11), 16-28.

Kitindi, E. G., Magembe, B. A. S., \& Sethibe, A. (2007). Lending decision making and financial information: The usefulness of corporate annual reports to lenders in Botswana. The International Journal of Applied Economics and Finance, 1(2), 55-66.

Kwok, H. (2002). The effect of cash flow statement format on lenders' decisions. The International Journal of Accounting, 37(3), 347-362.

Marian, Y. J. W. T., Lui, G., \& Lew, A. Y. (2002). The expectations-performance gap in financial reporting from the perspective of Hong Kong bank loan officers. Pacific Accounting Review, 14(1), 1-22.

Ministry of Finance. (2013). Vietnamese Accounting Standard No. 21-24-28 (based on the Decision of Minister, Hanoi, Vietnam).

Mirshekary, S., \& Saudagaran, S. M. (2005). Perceptions and characteristics of financial statement users in developing countries: Evidence from Iran. Journal of International Accounting, Auditing, and Taxation, 14(1), 33-54.

Nguyen, P. S. (2008). Enhancing the usefulness of financial statements of Vietnamese enterprise at current period (The Ph.D. dissertation).

Nguyen, V. T., Le, T. B. N., \& Jerman, R. (2007). Institutional impact to the process of making decision: Case study for banking of SMEs in US and Vietnam. Retrieved from http://www.apim.edu.vn/

Nichols, L. M. (1997). An investigation of the effect of reporting changes proposed by the AICPA on lending decisions. Journal of Applied Business Research, 13(2), 47-53.

Stanga, K. G., \& Benjamin, J. J. (1978). Information needs of bankers. Management Accounting, 59, 17-21. 